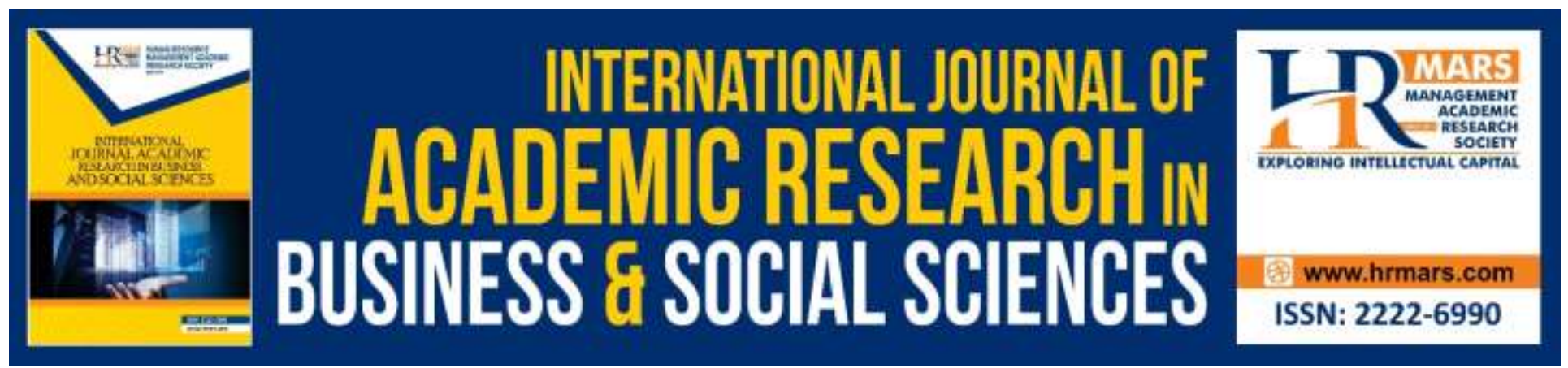

\title{
Improving Mathematical Understanding and Motivation of Students Through Contextual Learning Approaches Using Autograph Software
}

\author{
Husna, M. Ikhsan, Yusrizal
}

To Link this Article: http://dx.doi.org/10.6007/IJARBSS/v10-i6/7289

DOI:10.6007/IJARBSS/v10-i6/7289

Received: 13 March 2020, Revised: 29 April 2020, Accepted: 20 May 2020

Published Online: 16 June 2020

In-Text Citation: (Husna et al., 2020)

To Cite this Article: Husna, Ikhsan, M., \& Yusrizal. (2020). Improving Mathematical Understanding and Motivation of Students Through Contextual Learning Approaches Using Autograph Software. International Journal of Academic Research in Business and Social Sciences, 10(6), 311-328.

Copyright: (C) 2020 The Author(s)

Published by Human Resource Management Academic Research Society (www.hrmars.com)

This article is published under the Creative Commons Attribution (CC BY 4.0) license. Anyone may reproduce, distribute, translate and create derivative works of this article (for both commercial and non-commercial purposes), subject to full attribution to the original publication and authors. The full terms of this license may be seen

at: http://creativecommons.org/licences/by/4.0/legalcode

Vol. 10, No. 6, 2020, Pg. 311 - 328

http://hrmars.com/index.php/pages/detail/IJARBSS

JOURNAL HOMEPAGE

Full Terms \& Conditions of access and use can be found at

http://hrmars.com/index.php/pages/detail/publication-ethics 


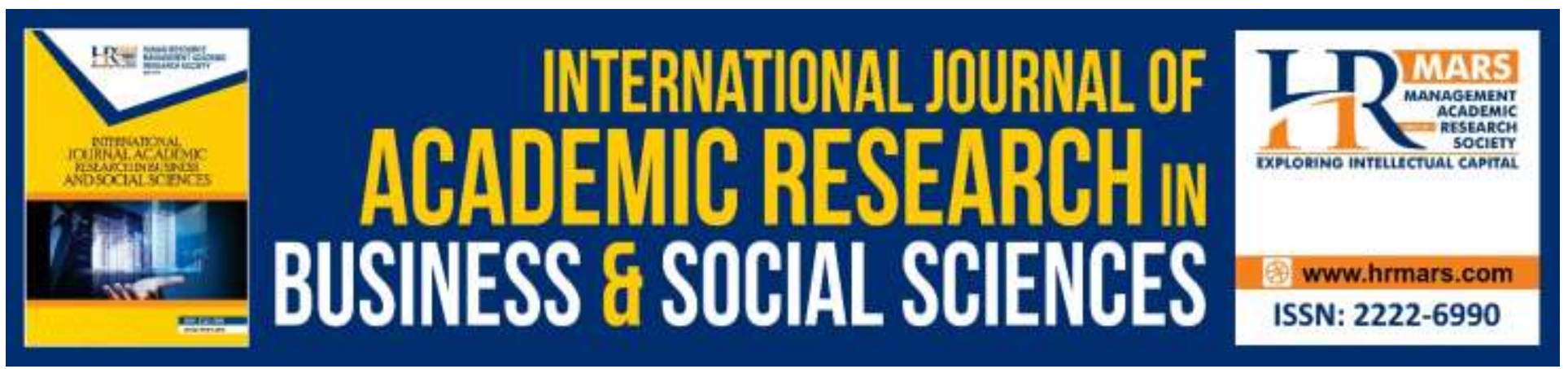

\title{
Improving Mathematical Understanding and Motivation of Students Through Contextual Learning Approaches Using Autograph Software
}

\author{
Husna ${ }^{1}$, M. Ikhsan², Yusrizal ${ }^{3}$ \\ ${ }^{1,2}$ Mathematics Education Program, Universitas Syiah Kuala, Banda Aceh, Indonesia, ${ }^{3}$ Physics \\ Education Program, Universitas Syiah Kuala, Banda Aceh, Indonesia \\ Email: yusrizal@fkip.unsyiah.ac.id
}

\begin{abstract}
The ability of mathematical understanding and motivation to learn is very necessary for students to take part in mathematics learning. This study aims to determine the increase in mathematical understanding and learning motivation of students who obtain mathematics learning through contextual approach using autograph software with students who obtain conventional mathematics learning, and analyze the interactions based on the level of students' initial mathematical abilities. This research is an experimental with a pretest-posttest control group design. The population of this study was all Year 10 students at SMK Negeri 1 Meulaboh, Aceh, Indonesia, the sample was 60 students with randomly selected from 165. Data analysis was performed by two-way ANOVA. The results showed that there was an increase in the ability of mathematical understanding and learning motivation of students through contextual approach using autograph software better than conventional learning; there is no interaction between learning approaches and students' initial mathematical abilities towards mathematical understanding ability, and there is an interaction between learning approaches and students' initial mathematical abilities towards student learning motivation. The teacher is expected to be able to expand the application of learning with a softwareassisted contextual approach to improve students' mathematical understanding and motivation.
\end{abstract}

Keywords: Mathematical understanding, motivation to learn, contextual approach, Autograph Software.

\section{Introduction}

Understanding ability is one of the five abilities that are essential in learning mathematics that need attention. The understanding ability possessed by each student is not the same, depending on the ideas that are owned and the relation between existing ideas and new ideas. Students are said to understand mathematical concepts or facts if they can explain the concepts or mathematical facts in a simpler way (Qohar \& Sumarmo, 2013). 
INTERNATIONAL JOURNAL OF ACADEMIC RESEARCH IN BUSINESS AND SOCIAL SCIENCES Vol. 10, No. 6, June, 2020, E-ISSN: 2222-6990 @ 2020 HRMARS

Based on the Trends study in the International Mathematics and Science Study (TIMSS) in 2015, the achievements of Indonesian students in mathematics were ranked 45th out of 50 participating countries. Similarly, according to Suprayitno, one of the subjects whose average National Examination (UN) level of SMA/SMK/MA is declining is mathematics (Mediani, 2018). Likewise the facts in the field, most students have not been able to master the concept of subject matter because of the lack of students 'understanding of the basic concepts of the subject matter so that it can be said that students' mathematical understanding is still low. This is supported by Wahyudin (2009) statement, one of the causes of weak students in mathematics is lack of understanding ability to recognize basic mathematical concepts related to the subject being studied.

Another factor that causes a low ability of students' mathematical understanding is the material learned by students is less meaningful. The cause comes from the students themselves, the learning methods used by the teacher, or the learning environment that relates to each other. Mathematical learning has been conveyed to students informally, students only get information from the teacher so that the degree of attachment can be said to be low (Turmudi, 2010). Similarly, according to Slettenhar (Fuadi, 2016) mathematics learning does not involve students active learning, less emphasis on understanding students and students only accept teacher explanations.

The success of mathematics learning is also supported by psychological aspects, namely student motivation towards learning done by teachers in the classroom. As expressed by Slameto (2015) motivation is a feeling of liking and attraction to a thing or activity, without anyone telling. Motivation to learn is internal and external encouragement to students who are learning to make behavioral changes. Indicators of learning motivation both intrinsic and extrinsic can be classified as follows, namely the desire and desire to succeed, encouragement and needs in learning, hopes and aspirations for the future, appreciation in learning, interesting activities in learning, a conducive learning environment, thus enabling someone study well (Uno, 2014).

Based on the preliminary study at SMK Negeri 1 Meulaboh, information was obtained that students' mathematical understanding abilities and motivation to learn mathematics were still low. In the process of learning mathematics, there are still many students who do not understand the concept of subject matter. In addition, students are lazy to do mathematical assignments given by the teacher because they find it difficult so they are less interested in completing the task as a result of copying a friend's work. The low ability of mathematical understanding and student learning motivation can also be seen also from the value of the final semester exam in mathematics students in class X of SMK Negeri 1 Meulaboh are still unsatisfactory. Only 76 students or $46.06 \%$ completed the KKM score from 165 students who took the mathematics exam.

Learning that links subject matter with the context of life and the needs of students will increase learning motivation and will make the teaching and learning process more efficient andeffective. This form of learning is what is called contextual learning. Contextual Teaching and Learning (CTL) is a learning concept that helps teachers associate subject matter (material) with real world situations and motivates students to make connections between knowledge and its application in their lives (Hosnan, 2014).

Contextual Teaching and Learning (CTL) approach makes students more interested in learning so that it can indirectly improve the ability of mathematical understanding and motivation to learn (Mulyati, 2008; Rahmadona \& Fitriyani, 2011). Several previous studies (Al-Siyam \& Sundayana, 2014) also found the advantages of contextual learning rather than conventional learning in improving students' mathematical understanding skills. 
INTERNATIONAL JOURNAL OF ACADEMIC RESEARCH IN BUSINESS AND SOCIAL SCIENCES

Vol. 10, No. 6, June, 2020, E-ISSN: 2222-6990 @ 2020 HRMARS

Learning mathematics using media based on computer technology also helps students to generate motivation to learn and understand subject matter so that learning activities are more efficient and effective. The implementation of learning with a contextual approach will be maximized through media based on computer technology. This is also in line with the expectations of the 2013 curriculum contained in Permendikbud No. 65 of 2013 concerning the standards of the primary and secondary education process in paragraph 13, namely the use of information and communication technology to improve the efficiency and effectiveness of learning. One of the software that can be used in learning mathematics is autograph software. The contextual learning approach assisted by autograph software is very appropriate to be used to improve students' mathematical understanding and motivation.

The research questions of this study are; is the improvement of students' mathematical understanding abilities using a contextual learning approach assisted by autograph software better than those using conventional learning ?; is the increase in students' learning motivation using a contextual learning approach assisted by autograph software better than those using conventional learning ?; Is there an interaction between the learning approach and students 'initial mathematical abilities with students' mathematical understanding abilities ?; and is there an interaction between learning approaches and students' initial mathematical abilities on student motivation?

\section{Method}

This research is an experimental research with a quantitative approach. Quantitative research is testing a theory by testing specific hypotheses, then collecting data to support or refute these hypotheses (Creswell, 2010). This quantitative research aims to find out the improvement of students' mathematical understanding and learning motivation abilities that obtain learning using a contextual learning approach assisted by autograph software.

The experimental design used in this study was a pretest-posttest control group design, which consisted of two research groups namely the experimental class (treatment class) is a group of students whose learning uses a contextual learning approach assisted by autograph software and the control group (control class) is a group of students whose learning uses conventional learning approaches. The experimental method aims to test the impact of a treatment on which is controlled by other factors that may also affect these results (Creswell, 2010).

The population in this study were all grade X students of SMK Negeri 1 Meulaboh. The selection of this school as a place of research is based on the ability of students belonging to the medium level and contextual learning approaches suitable to be applied in vocational schools, because vocational subject matter is more likely to be experienced by students in their daily lives. Samples were randomly selected by simple random sampling technique. According to Usman (2006) simple random sampling that is every element of the whole population has the same opportunity to be chosen. Based on this technique two classes from seven existing $X$ classes were selected, namely class $X$ AK 2 (experimental class) and class X AK1 (control class).

The instruments used in this study were test and non-test. The test instrument consisted of pretest and posttest. Pretest is a test of prerequisite material, while posttest is a test of mathematical understanding. Both of the test instruments are in the form of description questions consisting of 4 items. Non-test instruments used in this study were learning motivation questionnaires given to experimental and control class students at the beginning and end of learning activities in the form of statement sheets. Data obtained from the results of the pre-test and post-test were analyzed using 
INTERNATIONAL JOURNAL OF ACADEMIC RESEARCH IN BUSINESS AND SOCIAL SCIENCES Vol. 10, No. 6, June, 2020, E-ISSN: 2222-6990 @ 2020 HRMARS

the ANOVA test with a significance level of 0.05 ; to see an increase in students' mathematical understanding abilities and motivation to learn and the interaction between learning approaches and student levels.

\section{Results and Discussion}

Data obtained and analyzed in this study were sourced from the mathematical understanding ability test scores. From these scores calculated normalized gain ( $\mathrm{N}$-Gain) ability of mathematical understanding of both the experimental class and the control class. The following is a description of the value of pretest, posttest, and $\mathrm{N}$-gain in both classes, namely the experimental class and the control class.

Table 1. Score Data on Mathematical understanding of Students in Experimental and Control Classes

\begin{tabular}{|c|c|c|c|c|c|c|c|c|c|c|c|}
\hline \multirow{2}{*}{ Test } & \multirow{2}{*}{$\begin{array}{l}\text { Skor } \\
\text { Ideal }\end{array}$} & \multicolumn{5}{|c|}{ Experiment Class } & \multicolumn{5}{|c|}{ Control Class } \\
\hline & & $\mathrm{N}$ & $x_{\min }$ & $x_{\max }$ & $\bar{x}$ & SD & $\mathrm{N}$ & $x_{\min }$ & $x_{\max }$ & $\bar{x}$ & SD \\
\hline Pretes & 27 & 30 & 2 & 15 & 7,23 & 2,73 & 30 & 3 & 14 & 7,40 & 2.59 \\
\hline Postes & 27 & 30 & 17 & 27 & 21,53 & 2.91 & 30 & 14 & 26 & $\begin{array}{l}20,1 \\
0\end{array}$ & 2,78 \\
\hline $\mathrm{N}$-gain & & & 0,60 & 1,00 & 0,73 & 0,14 & & 0,48 & 0,79 & 0,66 & 0,11 \\
\hline
\end{tabular}

Table 1 shows that the average pretest ability of the experimental and control class mathematical comprehension is 7.23 and 7.40 from the ideal maximum score of 27 . The average pretest of the two classes is relatively the same, this indicates that students' initial mathematical abilities in both classes before learning relatively the same. Furthermore, to prove whether the pretest data between the experimental class and the control class has a difference or not significantly, then Kolmogorov-Smirnova's average difference test is performed on the data of the two classes using a significant level $\alpha=0.05$, the criteria reject $\mathrm{HO}$ if $\mathrm{p}$ - value (sig.) $<\alpha$ and accept $\mathrm{HO}$ if $\mathrm{p}$-value (sig.) $\geq \alpha$. The results of the normality test can be seen in Table 2 . below:

Table 2. Normality Test Results Score Pretend Mathematical Understanding Ability

\begin{tabular}{|l|l|l|l|l|l|l|}
\hline \multirow{2}{*}{ Result } & \multirow{2}{*}{ Class } & \multicolumn{3}{|l|}{ Kolmogorov-Smirnov $a$} & \multirow{2}{*}{ Conclusion } & \multirow{2}{*}{ Information } \\
\cline { 3 - 5 } & & Statistic & $D f$ & Sig. & & \\
\hline \multirow{2}{*}{ Pretest } & Experiment & 0,134 & 30 & 0,178 & Accept $\mathrm{H}_{0}$ & Normal \\
\cline { 2 - 7 } & Control & 0,109 & 30 & 0,200 & Accept $\mathrm{H}_{0}$ & Normal \\
\hline
\end{tabular}

Based on Table 2. above, it can be seen that the pretest scores on the ability of mathematical comprehension of the experimental class students and the control class both have sig values. 0.178 and 0.200 more than the value of $\alpha$ which is 0.05 . This means that $\mathrm{HO}$ is accepted or in other words the pretest data of the experimental class and the control class come from populations that are normally distributed.

Furthermore, the statistical test used is the Levene's Test with testing criteria at a significant level $\alpha=0.05$, then accept $\mathrm{HO}$ if $\mathrm{p}$-value (sig.) $>\alpha$ and reject $\mathrm{HO}$ if $\mathrm{p}$-value (sig.) $\leq \alpha$. The homogeneity test results can be seen as follows: 
INTERNATIONAL JOURNAL OF ACADEMIC RESEARCH IN BUSINESS AND SOCIAL SCIENCES Vol. 10, No. 6, June, 2020, E-ISSN: 2222-6990 @ 2020 HRMARS

Table 3. Homogeneity Test Results Score Variance Pretend Ability of Mathematical Understanding Experimental and Control Classes

\begin{tabular}{|l|l|l|l|l|l|l|}
\hline Capability Aspects & $\begin{array}{l}\text { Levene } \\
\text { Statistic }\end{array}$ & $d f_{1}$ & $d f_{2}$ & Sig. & Conclusion & Information \\
\hline $\begin{array}{l}\text { Mathematical } \\
\text { Understanding }\end{array}$ & 0.001 & 1 & 58 & 0,976 & Accept $\mathrm{H}_{0}$ & Homogen \\
\hline
\end{tabular}

Based on Table 3 for the homogeneity test, the Levene Statistic (F) value is 0.001 with a significant value of 0.976 . The significance value is greater than the significance level $\alpha$, which is 0.05 , so it can be said that the null hypothesis which states the sample variance of both homogeneous classes is accepted. That is, the two classes of mathematical understanding score data have homogeneous variances.

Based on the results of testing for normality and homogeneity in the pretest score, the data of the two classes are normally distributed and the variance of the two classes is homogeneous, so the test is continued by testing the similarity of the two mean values. Testing using one way anova with the help of SPSS 16 program with a significance level of $\alpha=0.05$. The testing criteria reject $\mathrm{H}_{0}$ if sig. (significant) $\leq 0.05$. The statistical hypothesis is as follows:

$\mathrm{H}_{0}: \mu_{p e}=\mu_{p k}$

$\mathrm{H}_{\mathrm{a}}: \mu_{p e} \neq \mu_{p k}$

Information

$\mathrm{HO}=$ There is no significant difference in the pretest ability of students' mathematical understanding using the software-assisted contextual learning approach with students using conventional learning.

$\mathrm{Ha}=$ There is a significant difference in the pretest ability of students' mathematical comprehension using a software autograph-assisted contextual learning approach with students using conventional learning.

The results of the test analysis of the difference in the average pretest ability of experimental class mathematical comprehension and control class can be presented in the following table:

Table 4. Data of Test Results Differences in Mean Pretest Mathematical understanding of Students in Experimental Classes and Control Classes

\begin{tabular}{|r|l|l|l|l|l|}
\hline & Sum of Squares & df & Mean Square & F & Sig. \\
\hline Between Groups & 0.417 & 1 & 0.417 & 0.059 & 0.809 \\
Within Groups & 410.576 & 58 & 7.079 & & \\
Total & 410.983 & 59 & & & \\
\hline
\end{tabular}

Based on Table 4, it can be seen that the results of the difference test on the average of the two groups are 0.809 , which means that it is greater than the significance level $=0.05$ so that $\mathrm{H}_{0}$ is accepted. Thus it can be concluded that there is no significant difference between the mean pretest ability of the experimental class mathematical understanding and the mean pretest ability of the mathematical comprehension of the control class students. 
INTERNATIONAL JOURNAL OF ACADEMIC RESEARCH IN BUSINESS AND SOCIAL SCIENCES Vol. 10, No. 6, June, 2020, E-ISSN: 2222-6990 @ 2020 HRMARS

\section{Data Analysis of $\mathbf{N}$-Gain Mathematical Understanding}

Increased ability of mathematical understanding achieved by students is used normalized $\mathrm{N}$ gain data, so that the data analyzed in this study are normalized $\mathrm{N}$-gain scores. The average normalized $\mathrm{N}$-gain score is an illustration of the improvement in the ability of good mathematical understanding of learning by using a contextual learning approach assisted by software autographs and conventional learning. The results of the $\mathrm{N}$-gain average mathematical understanding of the two classes can be seen in Table 5. below:

Table 5. Descriptive Statistics Data N-Gain Mathematical Understanding Students

\begin{tabular}{|r|r|r|r|}
\hline Class & $\mathrm{N}$ & Mean & Standard Deviation \\
\hline Experiment & 30 & 0,73 & 0,14 \\
\hline Control & 30 & 0,66 & 0,11 \\
\hline
\end{tabular}

From Table 5, the average $\mathrm{N}$-gain of the experimental and control classes is 0.73 and 0.66 . From these data it can be seen that the increase in the ability of mathematical understanding of the experimental class students is better than the control class. To show that an increase in mathematical understanding of experimental class students is better than the control class, further statistical tests are needed.

The statistical test used is Kolmogorov-Smirnov in the data of the two classes with a significant level of $\alpha=0.05$, the criteria reject $H_{0}$ if $p$-value (sig.) $A \alpha$ and accept $H_{0}$ if $p$-value (sig.) $\geq \alpha$. The results of the normality test can be seen in Table 6 . below:

Table 6. Results of N-Gain Normality Test for Mathematical Understanding

\begin{tabular}{|l|l|l|l|l|l|l|}
\hline \multirow{2}{*}{ Result } & \multirow{2}{*}{ Class } & \multicolumn{3}{|l|}{ Kolmogorov-Smirnov } & \multirow{2}{*}{ Conclusion } & \multirow{2}{*}{ Information } \\
\cline { 3 - 6 } & & Statistic & $D f$ & Sig. & & \\
\hline \multirow{2}{*}{ N_Gain } & Experiment & 0,152 & 30 & 0,075 & Accept $\mathrm{H}_{0}$ & Normal \\
\cline { 2 - 7 } & Control & 0,087 & 30 & 0,200 & Accept $\mathrm{H}_{0}$ & Normal \\
\hline
\end{tabular}

Based on Table 6, it can be seen that the sig value. the experimental class is 0.075 and the control class is 0.200 means that the two classes are greater than $\alpha=0.05$. This means that the normalized gain data ( $\mathrm{N}-$ Gain) for mathematical understanding is normally distributed.

The next step is to test the homogeneity of the two data with the formulation of the testing hypothesis as follows:

$\mathrm{H}_{0} \quad$ : variance of the $\mathrm{N}$-gain score of the experimental group and homogeneous control

$\mathrm{Ha}$ : the variance of the $\mathrm{N}$-gain score in the experimental and control groups was not homogeneous

The statistical test used is the Levene's Test with the testing criteria at a significant level of $\alpha$ $=0.05$, the criteria accept $\mathrm{HO}$ if $\mathrm{p}$-value (sig.) $>\alpha$ and reject $\mathrm{HO}$ if $\mathrm{p}$-value (sig.) $\leq \alpha$. The homogeneity test results can be seen in Table 7. below: 
INTERNATIONAL JOURNAL OF ACADEMIC RESEARCH IN BUSINESS AND SOCIAL SCIENCES Vol. 10, No. 6, June, 2020, E-ISSN: 2222-6990 @ 2020 HRMARS

Table 7. Homogeneity Test Results N-Gain Variance Mathematical Understanding Ability

\begin{tabular}{|l|l|l|l|l|}
\hline Ability Aspect & $\begin{array}{l}\text { Levene } \\
\text { Statistic }\end{array}$ & Sig. & Conclusion & Information \\
\hline Mathematical Understanding & 2,271 & 0,137 & Accept $H_{0}$ & Homogen \\
\hline
\end{tabular}

Based on Table 7 about the homogeneity test, the Levene Statistic (F) value is 1.127 with a significant value of 0.293 . The significance value is greater than the significance level $\alpha$, which is 0.05 , so it can be said that the null hypothesis which states the sample variance of both classes is accepted. That is, the two classes of $\mathrm{N}$-gain score mathematical data have homogeneous variance.

\section{Data Analysis of Student Learning Motivation}

The data obtained and analyzed in this study came from the learning motivation questionnaire scores. From this score calculated normalized gain ( $\mathrm{N}$-gain) motivation to learn both experimental class and control class. The following is a description of the values of pretest, posttest, and N-Gain in both classes namely the experimental class and the control class.

Table 8. Learning Motivation Score Data for Experimental and Control Classes

\begin{tabular}{|c|c|c|c|c|c|c|c|c|c|c|c|}
\hline \multirow{2}{*}{ Test } & \multirow{2}{*}{$\begin{array}{l}\text { Ideal } \\
\text { Score }\end{array}$} & \multicolumn{5}{|c|}{ Experiment Class } & \multicolumn{5}{|c|}{ Control Class } \\
\hline & & $\mathrm{N}$ & $x_{\min }$ & $x_{\max }$ & $\bar{x}$ & $S$ & $N$ & $x_{\min }$ & $x_{\max }$ & $\bar{x}$ & $\mathrm{~s}$ \\
\hline Pretest & 210 & 30 & 110 & 137 & 123,33 & 7,15 & $\begin{array}{l}3 \\
0\end{array}$ & 113 & 136 & 125,27 & 6,52 \\
\hline Postest & 210 & 30 & 164 & 185 & 171,17 & 5,89 & $\begin{array}{l}3 \\
0\end{array}$ & 158 & 176 & 168,03 & 5,06 \\
\hline$N$-gain & & & 0,054 & 0,66 & 0,55 & 0,052 & & 0,46 & 0,54 & 0,51 & 0,049 \\
\hline
\end{tabular}

Table 8 above shows that the average pretest of students 'motivation in the experimental and control classes is 123.33 and 125.27 from the ideal maximum score of 210 . The average pretest of the two classes is relatively the same, this indicates that students' initial motivation in both classes before learning are relatively the same.

Normality test on pretestmotivation learning data is also to find out whether the pretest data collected comes from populations that are normally distributed or not. The formulation of the testing hypothesis is as follows:

$\mathrm{H}_{0}$ : data on students' learning motivation pretest comes from those with normal distribution

Ha: students' learning motivation pretest data came from populations that were not normally distributed

The statistical test used is Kolmogorov-Smirnov on the data of the two classes through SPSS 16 using a significant level $\alpha=0.05$, the criteria reject $\mathrm{HO}$ if $\mathrm{p}$-value (sig.) A $\alpha$ and accept $\mathrm{HO}$ if $\mathrm{p}$-value (sig.) $\geq \alpha$. The results of the normality test can be seen in Table 9 below: 
INTERNATIONAL JOURNAL OF ACADEMIC RESEARCH IN BUSINESS AND SOCIAL SCIENCES Vol. 10, No. 6, June, 2020, E-ISSN: 2222-6990 @ 2020 HRMARS

Table 9. Normality Test Results Pretest Score Questionnaire Motivation Learning

\begin{tabular}{|l|l|l|l|l|l|l|}
\hline \multirow{2}{*}{ Aspect } & \multirow{2}{*}{ Class } & \multicolumn{3}{|l|}{ Kolmogorov-Smirnov } & \multirow{2}{*}{ Conclusion } & \multirow{2}{*}{ Information } \\
\cline { 3 - 5 } & & Statistic & $D f$ & Sig. & & \\
\hline $\begin{array}{l}\text { Motivation } \\
\text { Learning }\end{array}$ & Experiment & 0,078 & 30 & 0,200 & Accept $\mathrm{H}_{0}$ & Normal \\
\cline { 2 - 7 } & Control & 0,100 & 30 & 0,200 & Accept $\mathrm{H}_{0}$ & Normal \\
\hline
\end{tabular}

Based on Table 9, the results of the questionnaire scores on the students' motivation in the experimental class and the control class both have sig values. the same is 0,200 more than the value $\alpha$ that is 0,05 . This shows that the pretest motivation data of the experimental class and the control class are normally distributed. Because both the experimental and control classes were normally distributed, then the variance homogeneity test was continued.

The next step is to test the homogeneity of the two data with the formulation of the testing hypothesis as follows:

$\mathrm{HO}: \sigma_{1}^{2}=\sigma_{2}^{2}$ : the variance of the pretest score of the experimental group and homogeneous control $\mathrm{HO}: \sigma_{1}^{2}=\sigma_{2}^{2}$ : the variance of the pretest score of the experimental group and the control is not homogeneous

The statistical test used is the Levene's Test with the testing criteria at a significant level of $\alpha=0.05$, the criteria accept $\mathrm{HO}$ if $\mathrm{p}$-value (sig.) $>\alpha$ and reject $\mathrm{HO}$ if $\mathrm{p}$-value (sig.) $\leq \alpha$. The results of the homogeneity test can be seen in Table 4.10 below:

Table 10. Homogeneity Test Results Variance Motivation Pretest Score Studying Experimental and Control Class Students

\begin{tabular}{|l|l|l|l|l|}
\hline & $\begin{array}{l}\text { Levene } \\
\text { Statistic }\end{array}$ & Sig. & Conclusion & Information \\
\hline Learning Motivation & 0.155 & 0.695 & Accept $\mathrm{H}_{0}$ & Homogen \\
\hline
\end{tabular}

Based on Table 10 about the homogeneity test, the Levene Statistic (F) value is 0.155 with a significant value of 0.695 . The significance value is greater than the significance level $\alpha$, which is 0.05 , so it can be said that the null hypothesis which states the sample variance of both homogeneous classes is accepted. This means that both classes of learning motivation pretest scores have homogeneous variances.

Tests for normality and homogeneity of pretest motivation data in the experimental class and control class showed that both classes were normally distributed and the variances of the two classes were also homogeneous, then the next step was to test the difference in the average of the two samples with one way anova test. The difference test of the average pretest score was done to prove that there was no significant difference between the initial motivation of the experimental group and the control group. The statistical hypotheses tested are:

$\mathrm{H}_{0}: \mu_{m e}=\mu_{m k}$

$\mathrm{H}_{\mathrm{a}}: \mu_{m e} \neq \mu_{m k}$

Information :

$\mathrm{H}_{0}=$ There is no significant difference in the average pretest of learning motivation of students who use a software-assisted contextual learning approach to students who use conventional learning. 
INTERNATIONAL JOURNAL OF ACADEMIC RESEARCH IN BUSINESS AND SOCIAL SCIENCES Vol. 10, No. 6, June, 2020, E-ISSN: 2222-6990 @ 2020 HRMARS

$\mathrm{Ha}=$ There are significant differences in the mean pretest of learning motivation of students who use the autographed software-assisted contextual learning approach with students who obtain conventional learning.

The results of the test analysis of differences in the average pretest of learning motivation of students in the experimental class and control class can be presented in Table 11 below:

Table 11. Data on Test Results Difference in Average Learning Motivation Pretest Students of Experimental Classes and Control Classes

\begin{tabular}{|r|r|r|r|r|r|}
\hline & Sum of Squares & $\mathrm{df}$ & Mean Square & $\mathrm{F}$ & Sig. \\
\hline Between Groups & 56.067 & 1 & 56.067 & 1.198 & 0.278 \\
Within Groups & 2714.533 & 58 & 46.802 & & \\
Total & 2770.600 & 59 & & & \\
\hline
\end{tabular}

From Table 11, it can be seen that the results of the difference test on the average of the two groups are obtained sig. 0.278 which means that it is greater than the significance level $=0.05$ so $\mathrm{H}_{0}$ is accepted. This means that there is no significant difference between the mean pretest motivation of students in the experimental class with students in the control class.

\section{N-Gain Analysis of Student Learning Motivation}

Increased student learning motivation towards mathematics used normalized $\mathrm{N}$-gain data. The data analyzed in this study are normalized $\mathrm{N}$-gain scores. The normalized $\mathrm{N}$-gain score is an illustration of the increase in motivation both using the contextual learning approach assisted by software autographs and conventional learning, completely can be seen in the appendix. The summary results can be seen in Table 12. below:

Table 12. Descriptive Statistics N-Gain Data on Student Learning Motivation

\begin{tabular}{|l|r|r|r|}
\hline \multicolumn{1}{|c|}{ Class } & $\mathrm{N}$ & Mean & Standard Deviation \\
\hline Experiment & 30 & 0.55 & 0.052 \\
\hline Control & 30 & 0.51 & 0.049 \\
\hline
\end{tabular}

Table 12 above shows the average $\mathrm{N}$-gain of the experimental class and the control class are 0.55 and 0.51 . The data can be assumed that the increase in student learning motivation in the experimental class is better than increasing the learning motivation of the control class students. To prove that the increase in student learning motivation in the experimental class is better than the control class, an average difference test is needed. However, before the average difference test is carried out the normality test and homogeneity test for $\mathrm{N}$-gain scores are carried out in both classes.

The statistical test used was Kolmogorov-Smirnov on the data of both classes through SPSS 16 using a significance level $\alpha=0.05$, the criteria reject $\mathrm{HO}$ if $\mathrm{p}$-value (sig.) $<\alpha$ and accept $\mathrm{HO}$ if $\mathrm{p}$-value (sig.) A $\alpha$. The normality test results can be seen in the following Table 13:

The statistical test used is Kolmogorov-Smirnov on the data of the two classes through SPSS 16 using a significance level of $\alpha=0.05$, the criteria reject $\mathrm{HO}$ if $\mathrm{p}$-value (sig.) $<\alpha$ and accept $\mathrm{HO}$ if $\mathrm{p}$-value (sig.) $\geq \alpha$. The normality test results can be seen in the following Table 13: 
INTERNATIONAL JOURNAL OF ACADEMIC RESEARCH IN BUSINESS AND SOCIAL SCIENCES Vol. 10, No. 6, June, 2020, E-ISSN: 2222-6990 @ 2020 HRMARS

Table 13. Results of the N-Gain Normality Test for Student Learning Motivation

\begin{tabular}{|l|l|l|l|l|}
\hline Classes & Kolmogorov-Smirnov & Sig. & Conclusion & Information \\
\hline Experiment & 0,115 & 0.200 & Terima $\mathrm{H}_{0}$ & Normal \\
\hline Control & 0,118 & 0.200 & Terima $\mathrm{H}_{0}$ & Normal \\
\hline
\end{tabular}

Based on Table 13, it can be seen that the value of sig. the experimental class and the control class were 0.200 , meaning the two classes were greater than $\alpha=0.05$. This means that the normalized gain data ( $\mathrm{N}$-Gain) for student motivation is normally distributed. Will be tested for variance homogeneity for both classes.

Furthermore, the statistical test used is the Levene's Test with testing criteria at a significant level of $\alpha=0.05$, the criteria accept $H_{0}$ if $p$-value (sig.) $>\alpha$ and reject $H 0$ if $p$-value (sig.) $\leq \alpha$. The homogeneity test results can be seen in Table 14. below:

Table 14. Homogeneity Test Results N-Gain Variance of Student Learning Motivation

\begin{tabular}{|l|l|l|l|l|}
\hline & $\begin{array}{l}\text { Levene } \\
\text { Statistic }\end{array}$ & Sig. & Conclusion & Information \\
\hline Student Learning Motivation & 0,003 & 0,959 & Accept $H_{0}$ & Homogen \\
\hline
\end{tabular}

Based on Table 14 about the homogeneity test, the Levene Statistic (F) value is 0.003 with a significant value of 0.959 . The significance value is greater than the significance level $\alpha$, which is 0.05 , so it can be concluded that the null hypothesis which states the sample variance of both homogeneous classes is accepted. That is, both classes of N-Gain learning motivation students have homogeneous variance.

\section{Hypothesis Testing 1}

The increase in the ability of students' mathematical understanding using software-assisted contextual learning approaches is better than students who use conventional learning.

$\mathrm{H}_{0}$ : There is no difference in the improvement of students' mathematical understanding skills using a software autograph-assisted contextual learning approach with students using conventional learning.

$\mathrm{H}_{\mathrm{a}}$ : Increasing the ability of mathematical understanding of students who use the contextualassisted software approach to autograph is better than students who use conventional learning.

Information

The statistical hypothesis proposed is as follows:

$$
\begin{aligned}
& \mathrm{H}_{0}: \mu_{g e}=\mu_{g k} \\
& \mathrm{H}_{\mathrm{a}}: \mu_{g e}>\mu_{g k}
\end{aligned}
$$

$\mu_{\mathrm{ge}}=\mathrm{N}$-gain average mathematical comprehension ability of the experimental class

$\mu_{\mathrm{gk}}=\mathrm{N}$-gain average ability of the control class mathematical understanding

One way anova test calculation uses SPSS 16.0 at the significance level $\alpha=0.05$ with the test criteria accepted $\mathrm{HO}$ if sig. (significant) significant level $(=0.05)$. From the results of the one way ANOVA test obtained a significant value of less than the significance level $=0.05$ which is equal to 0.024, meaning reject $\mathrm{HO}$ as shown in Table 15 below. 
INTERNATIONAL JOURNAL OF ACADEMIC RESEARCH IN BUSINESS AND SOCIAL SCIENCES Vol. 10, No. 6, June, 2020, E-ISSN: 2222-6990 @ 2020 HRMARS

Table 15. Average N-Gain Capability Difference Test Results Mathematical Understanding

\begin{tabular}{|r|r|r|r|r|r|}
\hline N-Gain & Sum of Squares & $\mathrm{df}$ & Mean Square & $\mathrm{F}$ & Sig. \\
\hline Between Groups & 0.081 & 1 & 0.081 & 5.338 & 0.024 \\
Within Groups & 0.876 & 58 & 0.015 & & \\
Total & 0.957 & 59 & & & \\
\hline
\end{tabular}

These results indicate that there are significantly differences in the improvement of students' mathematical understanding skills using the software-assisted contextual learning approach with students using conventional learning. This is because students show enthusiasm in learning with a contextual learning approach assisted by autograph software, they are helped to understand the subject matter so that learning activities are more efficient and effective. One of the benefits of using autograph software is to overcome students' difficulties in constructing images and being able to facilitate the correction of errors made by students (Karnasih, 2008).

Thus the first hypothesis that has been formulated in the research is that the increase in the ability of mathematical understanding of students using the contextual-assisted software autograph learning approach is better than students who use conventional learning are accepted. This result is supported by Ramadhani's research (2017), the increase in students' understanding ability through the autograph software-assisted learning model is higher than that obtained by conventional learning.

\section{Hypothesis Testing 2}

Increased learning motivation of students who use the contextual-assisted software approach to autograph learning is better than students who use conventional learning. The formulation of the hypothesis is:

$\mathrm{H}_{0}$ : There is no difference in the increase in student motivation using a software autographassisted contextual learning approach with students using conventional learning.

$\mathrm{Ha}$ Increased learning motivation of students who use the contextual-assisted software approach to autograph learning is better than students who use conventional learning.

The statistical hypothesis is:

Information:

$$
\begin{aligned}
& \mathrm{H}_{0}: \mu_{g e}=\mu_{g k} \\
& \mathrm{H}_{a}: \mu_{g e}>\mu_{g k}
\end{aligned}
$$

$\mu_{g e}=$ average $\mathrm{N}$-gain learning motivation of experimental class students

$\mu_{g e}=$ average $\mathrm{N}$-gain learning motivation of control class students

One way anova test calculation uses SPSS 16.0 at the significance level $\alpha=0.05$ with the test criteria accepted $\mathrm{HO}$ if sig. (significant) significant level $(=0.05)$. From the results of the one way ANOVA test, the significant value is less than the significance level $=0.05$ which is equal to 0.001 , meaning that it rejects $\mathrm{HO}$ as shown in Table 16. below.

Table 16. Test Results Difference in Average N-Gain Student Learning Motivation

\begin{tabular}{|r|r|r|r|r|r|}
\hline N-Gain & Sum of Squares & $\mathrm{df}$ & Mean Square & $\mathrm{F}$ & Sig. \\
\hline Between Groups & 0.034 & 1 & 0.034 & 13.484 & 0.001 \\
Within Groups & 0.147 & 58 & 0.003 & & \\
Total & 0.181 & 59 & & & \\
\hline
\end{tabular}


INTERNATIONAL JOURNAL OF ACADEMIC RESEARCH IN BUSINESS AND SOCIAL SCIENCES Vol. 10, No. 6, June, 2020, E-ISSN: 2222-6990 @ 2020 HRMARS

These results indicate that there are significantly differences in the increase in student motivation using an autographed software-assisted contextual learning approach with students who get conventional learning. This is due to learning mathematics by applying the contextual learning approach assisted by autograph software to make students more active in learning in class. Students are coordinated in small groups, through the guidance of the teacher to construct knowledge from existing experiences so that learning becomes interesting, enjoyable and makes students have the desire, challenges to successfully solve problems and lead to encouragement and needs in learning. Students can appreciate the usefulness of mathematics and are motivated to dare to present their work in front of the class, so they feel confident in the results they get.

Thus the second hypothesis that has been formulated in the study is that the increase in learning motivation of students who use the contextual-assisted software autograph learning approach is better than students who use conventional learning are accepted. This result is supported by the study of Karnasih and Rahman (2014), the average ability of students' understanding and motivation to learn using autograph software assisted learning is higher than those using learning without autograph software.

\section{Testing Hypothesis 3:}

There is no interaction between the learning approach and students 'initial mathematical abilities towards students' mathematical comprehension abilities. The formulation of the hypothesis is:

$\mathrm{H}_{0}$ : There is no interaction between the learning approach and the students 'early (high, medium, low) mathematical abilities towards students' mathematical comprehension abilities.

Ha: $\quad$ There is an interaction between the learning approach and the students 'initial mathematical abilities (high, medium, low) towards the students' mathematical understanding abilities.

After it is known that the experimental class and control class N-Gain data are normally distributed and have homogeneous data variance, to find out whether there is an interaction between learning factors (software autograph and conventional assisted learning approach) with students' initial mathematical ability factors (high, medium, low) on the ability of students' mathematical understanding then testing using Two Way Anova analysis on SPSS 16.0 with a significance level of $\alpha=0.05$. The testing criteria is Reject HO if the Sig ( $p$-value) value $<\alpha(\alpha=0.05)$. The results of the analysis are presented in Table 17.

Table 17. Interaction Analysis between Learning Approaches and KAM Students to Students' Mathematical Understanding Ability

\begin{tabular}{|l|l|l|l|l|l|}
\hline Source & $\begin{array}{l}\text { Type III Sum of } \\
\text { Squares }\end{array}$ & Df & $\begin{array}{l}\text { Mean } \\
\text { Square }\end{array}$ & $F$ & Sig \\
\hline Learning & 52.059 & 1 & 52.059 & 15.233 & 0.000 \\
\hline Level & 271.847 & 2 & 135.924 & 39.774 & 0.000 \\
\hline Learning*Level & 20.530 & 2 & 10.265 & 3.004 & 0.058 \\
\hline Error & 184.541 & 54 & 3.559 & & \\
\hline Total & 26501.000 & 60 & & & \\
\hline
\end{tabular}


INTERNATIONAL JOURNAL OF ACADEMIC RESEARCH IN BUSINESS AND SOCIAL SCIENCES

Vol. 10, No. 6, June, 2020, E-ISSN: 2222-6990 @ 2020 HRMARS

The analysis results from Table 17 show that the Sig. equal to 0.058 more than $\alpha=0.05, \mathrm{H}_{0}$ is accepted. This means that there is no interaction between the learning factors and the students 'initial mathematical ability factors (high, medium, low) towards improving students' mathematical understanding skills. Graphically, the interaction can be seen in Figure 1. below:

Estimated Marginal Means of Kemampuan Pemahaman Matematis

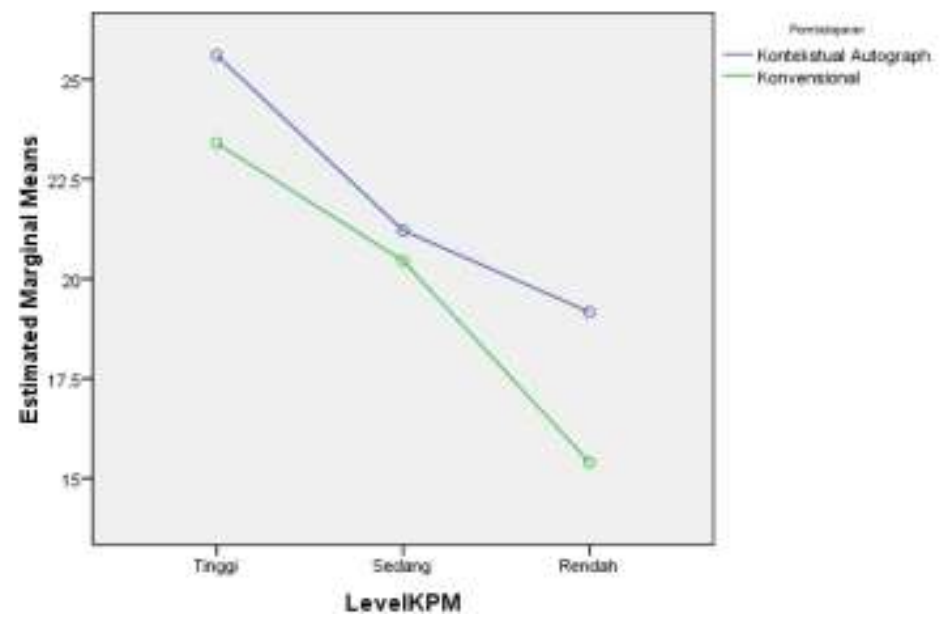

Figure 1. Interaction of Learning Factors with Early Mathematics Ability (KAM) on Students' Mathematical Understanding Ability in linear program material

Based on Figure 1, it can be seen that learning using a software-assisted contextual learning approach can improve students' mathematical understanding at high, medium and low levels. This means that the increase in the ability of mathematical understanding of students who use contextual learning approaches assisted by software autographs is better than increasing the ability of mathematical understanding of students who use conventional learning. However, each group of students has an increase in mathematical comprehension abilities that are not significantly different. This explains the increase in students 'mathematical understanding abilities purely influenced by the learning approach, not dependent on students' initial mathematical abilities (high, medium, and low). Thus, the contextual learning approach assisted by autograph software can be applied to all levels of students in an effort to improve students' mathematical understanding abilities.

So, it was concluded that there was no interaction between learning factors (contextual approach assisted by autograph software and conventional) with the factors of students 'initial mathematical abilities (high, medium, low) on increasing students' mathematical understanding abilities. The absence of this interaction shows that increasing students 'mathematical understanding abilities are not jointly influenced by students' initial mathematical abilities and contextual learning approaches assisted by autograph software. The results of Ramadhani's research (2017) also revealed that there was no interaction between learning models and students' initial mathematical abilities with mathematical understanding abilities. 
INTERNATIONAL JOURNAL OF ACADEMIC RESEARCH IN BUSINESS AND SOCIAL SCIENCES

Vol. 10, No. 6, June, 2020, E-ISSN: 2222-6990 @ 2020 HRMARS

Testing of Hypothesis 4

There is no interaction between the learning approach and students' initial mathematical abilities towards student learning motivation. To test the research hypothesis proposed above, the following hypotheses are formulated:

$\mathrm{H}_{0}$ : There is no interaction between the learning approach and students' initial mathematical abilities towards student learning motivation.

Ha: There is an interaction between learning approaches and students' initial mathematical abilities towards student learning motivation.

After knowing the group of $\mathrm{N}$-Gain learning motivation of experimental class students and controls is normally distributed and has a homogeneous variance of data then to find out whether there is an interaction between learning factors (software-assisted and conventional contextual learning approach) with students' initial mathematical abilities (high, moderate, low) towards student learning motivation then testing using Two Way Anova analysis on SPSS 16.0 with a significance level of $\alpha=0.05$. The testing criteria is Reject $H_{0}$ if the Sig ( $p$-value) value $<\alpha(\alpha=0.05)$. The results of the analysis are presented in the following table 18:

Table 18. Interaction Analysis between Student Learning Approaches and KAM towards Student Learning Motivation

\begin{tabular}{|l|l|l|l|l|l|}
\hline Source & $\begin{array}{l}\text { Type III Sum of } \\
\text { Squares }\end{array}$ & Df & $\begin{array}{l}\text { Mean } \\
\text { Square }\end{array}$ & $F$ & Sig \\
\hline Learning & 244.009 & 1 & 244.009 & 12.732 & 0.001 \\
\hline Level & 640.001 & 2 & 320.000 & 16.697 & 0.000 \\
\hline Learning*Level & 127.248 & 2 & 63.624 & 3.320 & 0.044 \\
\hline Error & 1034.912 & 54 & 19.165 & & \\
\hline Total & 1727744.000 & 60 & & & \\
\hline
\end{tabular}

From Table 18 can be seen the results of the analysis show that the value of Sig. the interaction between student level learning and learning motivation is 0.044 less than $\alpha=0.05, \mathrm{H}_{0}$ is rejected. This means that there is an interaction between the learning approach with the level of students (high, medium, low) on student learning motivation. Graphically, the interaction can be seen in figure 2 below: 


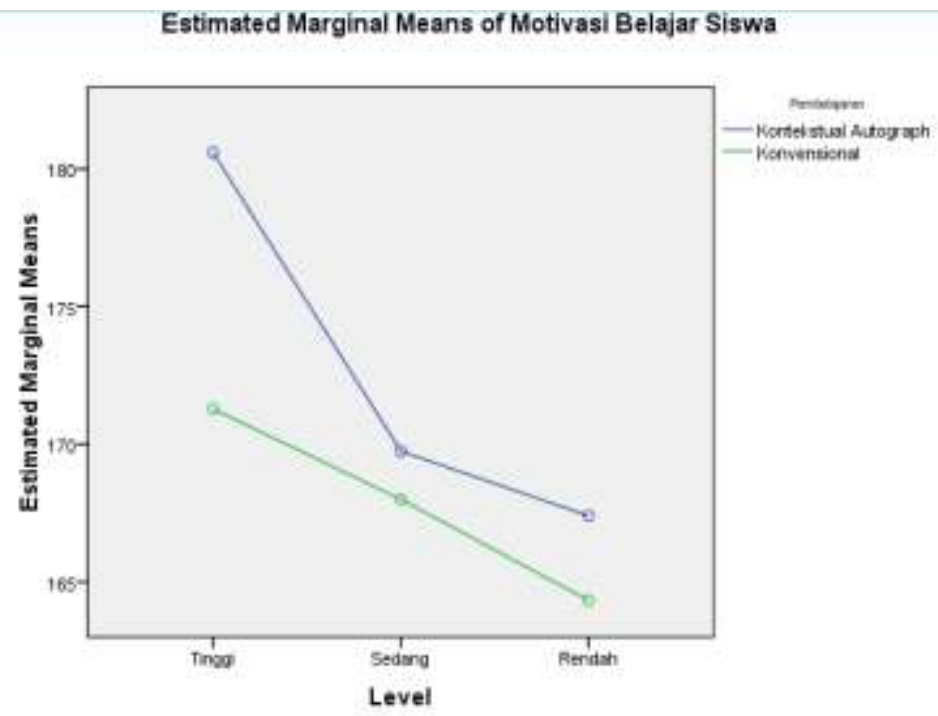

Figure 2. Interaction of Learning Factors with Early Mathematical Capability (KAM) on Student Motivation in Linear Program Materials

Based on Figure 2, it can be seen that there is a difference in the increase in the average learning motivation of students at the high, medium and low levels between students. Those who obtain learning use a software-assisted contextual learning approach to students who obtain conventional learning. So it can be concluded that there is an interaction between the learning approach and the students 'initial mathematical abilities towards students' learning motivation.

This result can be interpreted as an increase in student learning motivation in addition to being influenced by the learning approach also influenced by other factors. Sardiman (2014) states that there are two types of motivation, namely motivation that can arise from within the individual (intrinsic motivation) and motivation arising from outside the individual (extrinsic motivation). Students who are intrinsically motivated will do academic assignments because they like them while students who are extrinsically motivated will be involved in educational tasks to get rewarded or to avoid punishment (Ikhsan, 2008).

During the learning process with a contextual learning approach assisted by software autographs, students are given the opportunity to understand the subject matter with the help of software both with the teacher and group friends. The aim is to increase student enthusiasm and motivation in following the learning process. Intrinsic motivation can also be improved because of influences from outside the student, for example interesting learning for students, conducive conditions that are built by the teacher, dynamic communication between teacher-students, and fellow students, will tend to increase student motivation in learning.

The use of software autographs makes learning activities interesting, makes learning faster, meaningful and the contextual learning approach presents contextual problems that make students have desires, challenges to succeed in solving these problems and lead to encouragement and need for learning. This is in accordance with the indicators of learning motivation according to Uno (2016), namely the existence of desires and desires to succeed, the encouragement and need for learning, the existence of interesting activities in learning, and the existence of a conducive environment to enable a person to study well. 
INTERNATIONAL JOURNAL OF ACADEMIC RESEARCH IN BUSINESS AND SOCIAL SCIENCES Vol. 10, No. 6, June, 2020, E-ISSN: 2222-6990 @ 2020 HRMARS

\section{Conclusions AND Suggestions}

Conclusions in this study are an increase in the ability of mathematical understanding and learning motivation of students through contextual approach using autograph software better than conventional learning; there is no interaction between learning approaches and students' initial mathematical abilities towards mathematical understanding ability; and there is an interaction between learning approaches and students' initial mathematical abilities towards student learning motivation.

The results of this study indicate that the contextual learning approach can improve mathematical understanding and learning motivation. This is caused by the contextual learning process approach that is centered on students by applying the seven principles in learning, namely constructivism, inquiry, asking, learning communities, modeling, reflection, and authentic assessment. The learning process through contextual approach assisted by autograph software also makes learning activities more interesting, faster and meaningful and makes students have the desire, challenges to successfully solve problems and lead to encouragement and needs in learning. This is in accordance with indicators of learning motivation according to Uno (2014), namely the desire and desire to succeed, the encouragement and needs in learning, the existence of interesting activities in learning, and the existence of a conducive environment so that students can learn well.

There is no interaction between learning approaches and students' initial mathematical abilities towards mathematical understanding abilities. This means that contextual learning approaches can improve students 'mathematical understanding abilities for all levels of students' initial mathematical abilities. The results of the study also concluded that there was an interaction between the learning approach and students' initial mathematical abilities on student motivation. This can be interpreted as an increase in student learning motivation in addition to being influenced by the learning approach also influenced by other factors. Sardiman (2014) states that there are two types of motivation, namely motivation that can arise from within the individual (intrinsic motivation) and motivation arising from outside the individual (extrinsic motivation). Ikhsan (2008) also explains that students who are intrinsically motivated will do academic assignments because they like them while students who are extrinsically motivated will be involved in educational tasks to obtain rewards or to avoid punishment.

Based on the results of research and discussion, it is suggested that using the GeoGebra software through contextual learning approach as an alternative in developing students' mathematical abilities. Further researchers need to examine more deeply about the improvement of other mathematical abilities through contextual approaches using autograph software.

\section{References}

Al-Siyam, E., \& Sundayana, R. (2014). Perbandingan kemampuan pemahaman matematika antara siswa yang mendapatkan pembelajaran contextual teaching and learning (ctl) dan metakognitif. Jurnal Pendidikan Matematika, 3(1), 55-66.

Creswell, J. W. (2010). Research design: pendekatan kualitatif, kuantitatif, dan mixed. Yogyakarta: PT. Pustaka Pelajar.

Fuadi, R., Johar, R., \& Munzir, S. (2016). Peningkatan kemampuan pemahaman dan penalaran matematis melalui pendekatan kontekstual. Jurnal Didaktik Matematika, 3(1), 47-54.

Hosnan. (2014). Pendekatan saintifik dan kontekstual dalam pembelajaran abad 21. Bogor: Ghalia Indonesia. 
INTERNATIONAL JOURNAL OF ACADEMIC RESEARCH IN BUSINESS AND SOCIAL SCIENCES

Vol. 10, No. 6, June, 2020, E-ISSN: 2222-6990 @ 2020 HRMARS

Ikhsan, M. (2008). Meningkatkan prestasi dan motivasi siswa dalam geometri melalui pembelajaran berbasis teori van Hiele. Disertasi Doktor unpublished. Program Pascasarjana Univesitas Pendidikan Indonesia: Bandung.

Karnasih, I. (2008). ICT for teaching and learning mathematics. Paper Presentated in International Workshop. Medan: UNIMED.

Karnasih, I., \& Rahman, A. (2014). Integrasi software dinamis autograph dalam pembelajaran matematika menggunakan pendekatan penemuan terbimbing. Jurnal Pendidikan Matematika, 04(02), 143-160.

Mediani, M. (2018). Soal dipersulit, nilai UN SMA dan SMK se-Indonesia menurun. CNN Indonesia. Retrived from https://www.cnnindonesia.com/nasional/20180508201307-20-296712/soaldipersulit-nilai-un-sma-dan-smk-se-indonesia-menurun

Mulyati, S. (2010). Pengaruh pendekatan kontekstual dalam proses belajar mengajar matematika terhadap sikap, motivasi, dan hasil belajar siswa SMP. Retrived from http://repository.um.ac.id/id/eprint/64905

Qohar, A., \& Sumarmo, U. (2013). Improving mathematical communication ability and self regulation learning of junior high students by using reciprocal teaching. Indonesian Mathematical Society Journal on Mathematics Education, 4(1), 59-74.

Rahmadonna, S., \& Fitriyani. (2011). Penerapan pembelajaran kontekstual pada pelajaran matematika untuk meningkatkan motivasi belajar siswa SMA. Jurnal IImiah Pembelajaran,7(1), 76-95.

Ramadhani, R. (2017). Peningkatan pemahaman konsep dan kemampuan pemecahan masalah matematika siswa SMA melalui guided discovery learning berbantuan autograph. Jurnal Pengabdian dan Pemberdayaan Masrarakat.10(2).72-81.

Sardiman, A. M. (2014). Interaksi dan motivasi belajar mengajar. Jakarta: Rajawali Press.

Slameto. (2010). Belajar dan faktor yang mempengaruhinya. Jakarta: Rineka Cipta.

Turmudi. (2010). Landasan filsafat dan teori pembelajaran matematika (berparadigma eksploratif dan investigatif). Jakarta: Leuser Cita Pustaka.

Uno, H. B. (2014). Teori motivasi dan pengukurannya: analisis di bidang pendidikan. Jakarta: Bumi Aksara.

Usman, H., dan Setiady, A. P. (2006). Pengantar statistika. Jakarta: Bumi Aksara.

Wahyudin. (2010). Pembelajaran matematika dan pemecahan masalah. Bandung: Mandiri Bandung. 